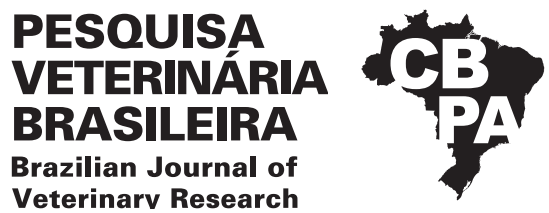

Pesq. Vet. Bras. 41:e06807, 2021

DOI: 10.1590/1678-5150-PVB-6807

Original Article

Livestock Diseases

ISSN 0100-736X (Print)

(cc) BY-NC

ISSN 1678-5150 (Online)

\title{
Poisonous plants for ruminants in the dairy region of Pernambuco, Northeastern Brazil ${ }^{1}$
}

\author{
Jaianne K.A. Melo², Taciana R.R. Ramos ${ }^{3}$, Luiz C.F. Baptista Filho ${ }^{3}$, Luana V. Cruz ${ }^{3}$, \\ Nathalia S. Wicpolt ${ }^{4}$, Silvio M.C. Fonseca ${ }^{4}$ and Fábio S. Mendonça ${ }^{4 *}$ (D)
}

\begin{abstract}
Melo J.K.A., Ramos T.R.R., Baptista Filho L.C.F., Cruz L.V., Wicpolt N.S., Fonseca S.M. \& Mendonça F.S. 2021. Poisonous plants for ruminants in the dairy region of Pernambuco, Northeastern Brazil. Pesquisa Veterinária Brasileira 41:e6807, 2021. Laboratório de Diagnóstico Animal, Universidade Federal Rural de Pernambuco, Rua Dom Manoel de Medeiros s/n, Dois Irmãos, Recife, PE 52171-900, Brazil. E-mail: fabio.mendonca@ufrpe.br

A survey carried out in the dairy region of Pernambuco was conducted to determine the most important poisonous plants for ruminants in the region. A total of 95 farmers from 19 municipalities were interviewed and the grazing areas of ruminants were inspected. According to the survey, the most important poisonous plants for ruminants were Manihot esculenta, Palicourea aeneofusca, Brachiaria decumbens, Indigofera suffruticosa, Ricinus communis and Cestrum axillare. Less reported classes of poisonous plants included nephrotoxic plants and plants that cause abortions or congenic malformations. Psychotria hoffmannseggiana, Psychotria colorata and Psychotria capitata were reported by farmers as the cause of sudden death in cattle. These plants should be better investigated to evaluate their importance as the cause of cattle deaths.
\end{abstract}

INDEX TERMS: Poisonous plants, ruminants, cyanogenic plants, monofluoracetate, disease of cattle, Brazil.

RESUMO.- [Plantas tóxicas para ruminantes na bacia leiteira de Pernambuco, Nordeste do Brasil.] Neste estudo prospectivo, realizou-se um levantamento sobre a ocorrência das principais plantas tóxicas e a ocorrência de intoxicações por plantas em ruminantes na bacia leiteira de Pernambuco. Para isso, foram entrevistados 95 produtores rurais de 19 municípios e as áreas de pastagem de ruminantes foram inspecionadas. De acordo com o levantamento, as plantas tóxicas mais importantes para ruminantes foram Manihot esculenta, Palicourea aeneofusca, Brachiaria decumbens, Indigofera suffruticosa e Ricinus communis. As classes menos importantes de plantas tóxicas incluíram plantas nefrotóxicas e plantas que causam abortos e malformações congênitas. Psychotria hoffmannseggiana, Psychotria colorata e Psychotria capitata foram relatadas por produtores rurais como a causa

\footnotetext{
${ }^{1}$ Received on December 6, 2020.

Accepted for publication on December 21, 2020.

${ }^{2}$ Postgraduate Program in Veterinary Medicine, Universidade Federal Rural de Pernambuco (UFRPE), Rua Dom Manoel de Medeiros s/n, Dois Irmãos, Recife, PE 52171-900, Brazil.

${ }^{3}$ Department of Veterinary Medicine, Universidade Federal do Agreste de Pernambuco (UFAPE), Av. Bom Pastor s/n, Boa Vista, Garanhuns, PE 55292-270, Brazil.

${ }^{4}$ Laboratory of Animal Diagnosis, Universidade Federal Rural de Pernambuco (UFRPE), Rua Dom Manoel de Medeiros s/n, Dois Irmãos, Recife, PE 52171900, Brazil. *Corresponding author: fabio.mendonca@ufrpe.br
}

de mortes súbitas em bovinos. Essas plantas devem ser investigadas melhor para avaliar sua importância como a causa de mortes de bovinos.

TERMOS DE INDEXAÇÃO: Plantas tóxicas, ruminantes, plantas cianogênicas, monofluoracetato, doença de bovinos, Brasil.

\section{INTRODUCTION}

The dairy region of Pernambuco is geographically located in the Agreste and Sertão territory. It covers a total area of $13.153 \mathrm{~km}^{2}$ and is composed of 27 municipalities, in which milk production and family farming are especially important for the economy of the Pernambuco's State. Recent data about raised ruminants in this dairy region pointed to a total of 838.487 bovines, 313.072 sheep and 135.385 goats (IBGE 2017). In this region, poisoning by plants in livestock remains a relevant cause of economic losses and several manuscripts reporting outbreaks of poisonings in ruminants have been published (Guaraná et al. 2011, Mendonça et al. 2012, Souza et al. 2012, Lima et al. 2013, Olinda et al. 2015, Andrade Neto et al. 2016, Brito et al. 2016, Almeida et al. 2017, Correia et al. 2017, Mendonça et al. 2018, Silva Filho et al. 2020).

There are a lot of situations leading to poisoning by plants in ruminants, but in general, the main reason occurs due to the scarcity of food or water deprivation and after transportation 
of animals. High pasture stocking rate and contamination of the hay are also important causes (Silva et al. 2006, Tokarnia et al. 2012). Another cause, the lack of knowledge concerning the occurrence of poisonous plants by farmers and professionals linked to the livestock is, in our opinion, one of the major causes for the occurrence of poisoning by plants in farm animals. For this reason, prospective surveys aiming to discover or elucidate the causes of poisonings remain relevant and comprises a significant tool for the diagnosis of animal diseases. Furthermore, the realization of prospective studies aiming to identify poisonous plants lead to the diagnosis of common diseases of livestock, and also emerging and transboundary diseases, because they put working together farmers, field veterinarians, animal health authorities and scientists.

This study is composed by a prospective survey and aimed to study the occurrence of poisonous plants for ruminants in the dairy region of the State of Pernambuco, Northeastern Brazil.

\section{MATERIALS AND METHODS}

This study was carried at the dairy region of Pernambuco State. For this, we interviewed 95 farmers from 19 municipalities: Angelim, Bom Conselho, Brejão, Caetés, Calçado, Canhotinho, Correntes, Garanhuns, Iati, Jucati, Jupi, Jurema, Lagoa do Ouro, Lajedo, Palmeirina, Paranatama, Saloá, São João and Terezinha (Fig.1). The climate in this region is semiarid, with high temperatures throughout the year, irregular/scarce rainfall and the vegetation is composed by the Brazilian Altitudinal Grasslands and Caatinga.

Technical visits were made on 5 farms per municipality and accounted 95 smalls to medium size farms, whose main source of income is the family farming. Those farms were selected based on the non-probabilistic sampling technique called snowball, which uses the reference chain, where the first farmer indicated the next one to compose the survey (Vinuto 2014).

The interview protocols consisted of the application of three investigative forms based on the methodology of Silva et al. (2006). Forms 1 and 2 were applied to all producers, while Form 3 was only applied to those who were interested in reporting outbreaks of poisoning by plants. At Form 1 farmers were asked about the poisonous plants already known by them according to a recognition of the existing species of poisonous plants cited in the scientific literature. For this, a booklet was prepared as illustrative material

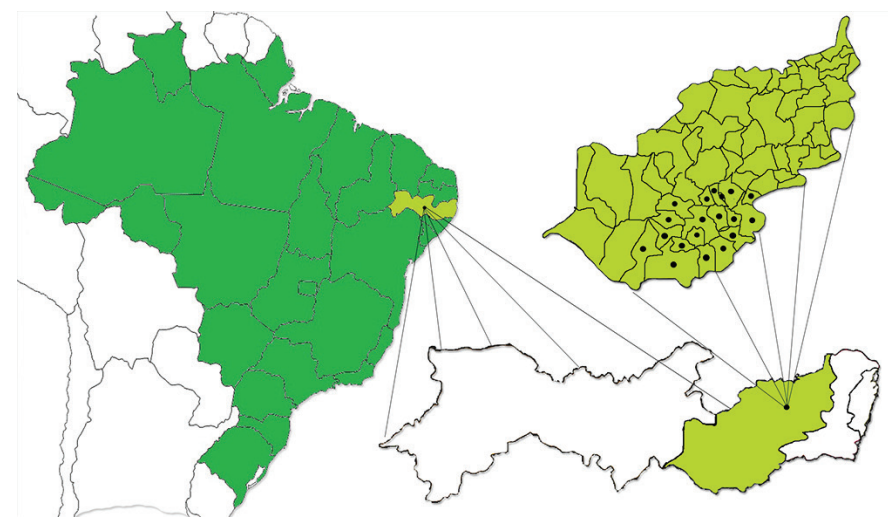

Fig.1. Geographic map of Brazil highlighting the Northeast region, the State of Pernambuco and, in the high magnification, the municipalities studied. according to Riet-Correa et al. (2011) and Tokarnia et al. (2012). At Form 2 the farmers reported poisonous plants recognized by them, but that one's without scientific support. Common names, affected animal species, affected organ system, and observed clinical signs were asked. After interviews, these plants were collected and identified botanically by species and genus. Form 3 concerned about the characteristics of the poisonings observed by the farmers.

Data analysis was performed in a descriptive manner, establishing a relationship between the variable's occurrence of poisonous plants and the frequency of outbreak's reports. Based on information obtained through the forms and field inspection, the qualitative and quantitative data were accounted for and grouped according to the absolute frequency (AF) and relative frequency (RF) of occurrence and subjected to a critical analysis.

The relative frequency of producers who recognized species of poisonous plants was obtained according to the following sentence:

$$
\mathrm{RF}_{\mathrm{PI}}=\frac{\mathrm{PR}}{\mathrm{T}} \times 100
$$

Where $\mathrm{RF}_{\mathrm{PI}}=$ relative frequency of plant identification, $\mathrm{PI}=$ number of times in which the plant was identified, and $\mathrm{T}=$ total amount of farmers interviewed.

The relative frequency of outbreaks of poisoning was calculated according to the following sentence:

$$
\mathrm{RF}_{\mathrm{Po}}=\frac{\mathrm{SI}}{\mathrm{TI}} \times 100
$$

Where $\mathrm{RF}$ = relative frequency according to a specific poisoning, $\mathrm{PO}=$ number of outbreaks of a specific plant poisoning, and $\mathrm{T}=$ total amount of poisonings in the region.

\section{RESULTS}

Farmers mentioned the occurrence of 36 species of poisonous plants in the dairy region of Pernambuco. Of these, 27 species were identified by our team during the pastures inspection and 21 species were associated with outbreaks of poisonings in ruminants. The frequency of occurrence of plants classes (Fig.2), most important poisonous plants (Fig.3) and the frequency of poisonings reported by farmers are shown in Table 1.

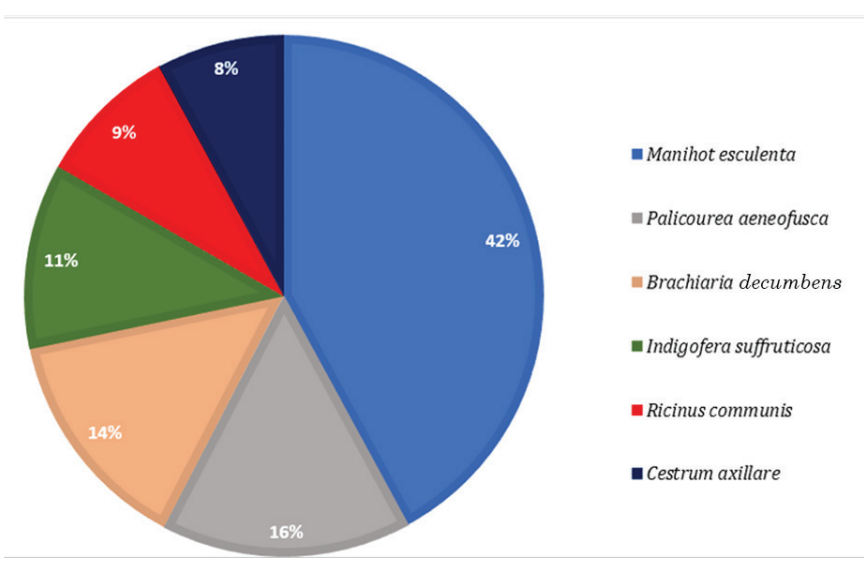

Fig.2. Frequency of occurrence of poisoning by toxic plants organized by classes. 


\section{Occurrence of poisonous plants and frequency of poisonings in ruminants}

Cyanogenic plants. Cyanogenic plants are widespread in the dairy region of Pernambuco, with high frequency of reports of outbreaks of poisoning in ruminants.

Manihot esculenta (Euphorbiaceae) is widely used in the region for human and animal consumption. It was mentioned by $83.15 \%(79 / 95)$ of farmers and was associated with 38 outbreaks of poisoning $(38 / 178,21.34 \%)$ in 14 municipalities. In total, it was cited as cause of the death of 137 cattle and 6 sheep with an acute clinical course: generally, right after ingestion of the cassava wastewater. According to reports, most of these poisonings were accidental because the owners also produce cassava's flour and the animals have access to the wastewater or to the cassava's bark, which is highly toxic.

Piptadenia macrocarpa (Leg. Mimosoideae) was identified by fifty-four farmers $(54 / 95,56.84 \%)$ that reported its occurrence in 16 municipalities. One famer $(1 / 178,0.56 \%)$ cited a case of poisoning in the municipality of Lajedo, where two cows were poisoned and died after consuming the leaves found on the ground after the tree's pruning.

Piptadenia viridiflora (Leg. Mimosoideae) was mentioned by twenty-four farmers $(24 / 95,25.26 \%)$ that informed knowing the plant and having it on their property, however, cases of poisonings were not reported.

Neurotoxic plants. The second class of poisonous plants most frequently found in the dairy region of Pernambuco was composed by plants that affect the nervous system.

Ricinus communis (Euphorbiaceae) was mentioned by sixty-four farmers $(64 / 95,67.36 \%)$ in 19 municipalities and 14 outbreaks of poisonings (14/178, 7.86\%) were accounted for being associated with the consumption of $R$. communis leaves. According to the farmers, cattle were the main species affected (29 in a total) and there was a history of poisoning in one goat. Most poisonings occurred after the ingestion of dried or wilted leaves and pericarps of pruned R. communis bushes. The municipalities where the cases occurred were Caetés, Palmeirina, Angelim, Canhotinho, Calçado, Jupi, Iati, Garanhuns, Brejão and Lagoa do Ouro. These cases were not fatal. The animals presented clinical signs consisted of drooling, staggering gait, mild bloat and recovered after a few hours.

The occurrence of Prosopis juliflora (Leg. Mimosoideae) was mentioned by seventy-nine farmers $(79 / 95,83.15 \%)$ and 8 outbreaks of poisoning $(8 / 178,4.49 \%)$ were reported

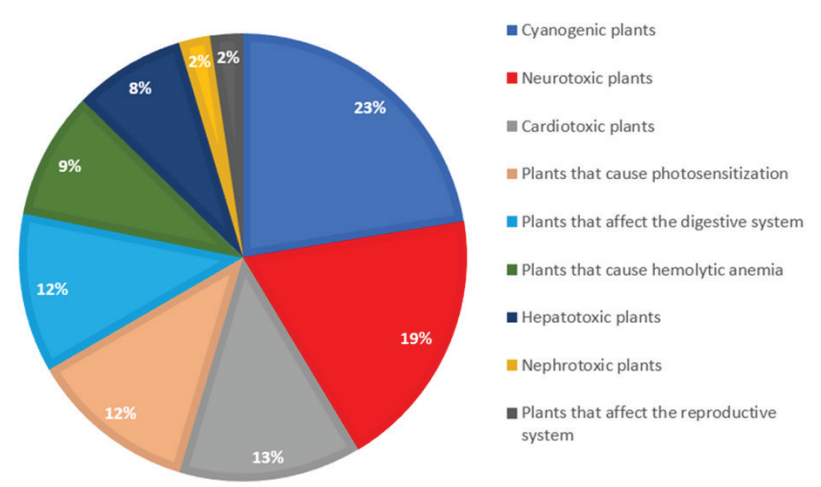

Fig.3. Most frequent poisonous plants associated with outbreaks of poisonings in ruminants. affecting cattle. In the region, farmers usually utilized $P$.juliflora as ruminant feed and they know that pods are poisonous for cattle and goats. For this reason, farmers normally use P.juliflora pods in a moderate amount and for a short time. Despite this, five outbreaks $(5 / 178,2.8 \%$ of the total outbreaks in the region), were reported associated with the supply of mesquite beans as animal feed in large amounts (more than $50 \%$ of the feed amount). Farmers reported that approximately 2-4 months after the beginning of the supply, the cattle presented difficulties in chewing, swallowing, protrusion of the tongue, emaciation and died.

Sixty-two farmers $(62 / 95,65.26 \%)$ mentioned the occurrence of Ipomoea asarifolia (Convolvulaceae) in the farms of 18 municipalities visited and six outbreaks $(6 / 178,3.37 \%)$ were accounted for. Outbreaks reported were mainly observed in cattle and occurred during the dry season, when there was scarcity of pastures and I. asarifolia remained green and tender. The farmers reported that poisonings occur mainly in calves, generally when they have been introduced in grazing paddocks infested by I. asarifolia. According to the reports, eighteen calves in the total were affected. These animals showed clinical signs of dyspnea, staggering, salivation, muscle tremors, and reluctance to walk. Four calves presented episodes of falls that evolved for permanent recumbency and death within 2 days after the observation of the first clinical signs.

During technical visits, Solanum paniculatum (Solanaceae) was observed in seventy nine $(79 / 95,83.15 \%)$ farms visited and four farmers $(4 / 178,2.24 \%)$ mentioned that they had witnessed outbreaks of poisoning in cattle in their properties during the dry season, after ingestion of S. paniculatum mixed with the grass. In the municipality of Bom Conselho 14 cattle died after presenting neurological clinical signs. In Caetés, 3 calves were poisoned and in the municipality of Brejão there was a case affecting five goats. All those animals died after presenting a similar clinical picture, which consisted of opisthotonus, muscle tremors, falls, motor incoordination, recumbency and hyperextension of the forelimbs.

Talisia esculenta (Sapindaceae), a tree whose fruits called "pitomba" widely consumed and appreciated by human beings in Northeastern Brazil, was mentioned as a plant regularly cultivated in the farms because these trees give shade for ruminants. Seventy-one farmers $(72 / 95,75.78 \%)$ had $T$. esculenta in their farms, but they were unaware of its toxic potential, except for one farmer which reported an outbreak between 2016 and 2017 in the municipality of Brejão. Ten cattle that consumed the fruits of T. esculenta given in the trough, presented motor incoordination, wide base stance, head tremors, bloat and severe muscle spasms and recovered between 8-15 days, afterwards the withdrawal of the supply. T. esculenta was found by our team in all the investigated municipalities.

Ipomoea carnea subsp. fistulosa and Ipomoea sericosepala (Convolvulaceae). Fourteen farmers (14/95, 14.73\%) in 11 municipalities mentioned the occurrence of I. carnea subsp. fistulosa in gardens, but not in pasture areas. There were no reports of poisonings associated with this plant and our team just found it in small amounts in the municipalities covered by this study. I. sericosepala (= Turbina cordata) was identified by twelve farmers $(12 / 95,12.63 \%)$ that reported the occurrence of this species in the municipalities of Brejão, Canhotinho, Calçado, Garanhuns, Jurema, Lajedo, Palmerina, Paranatama 


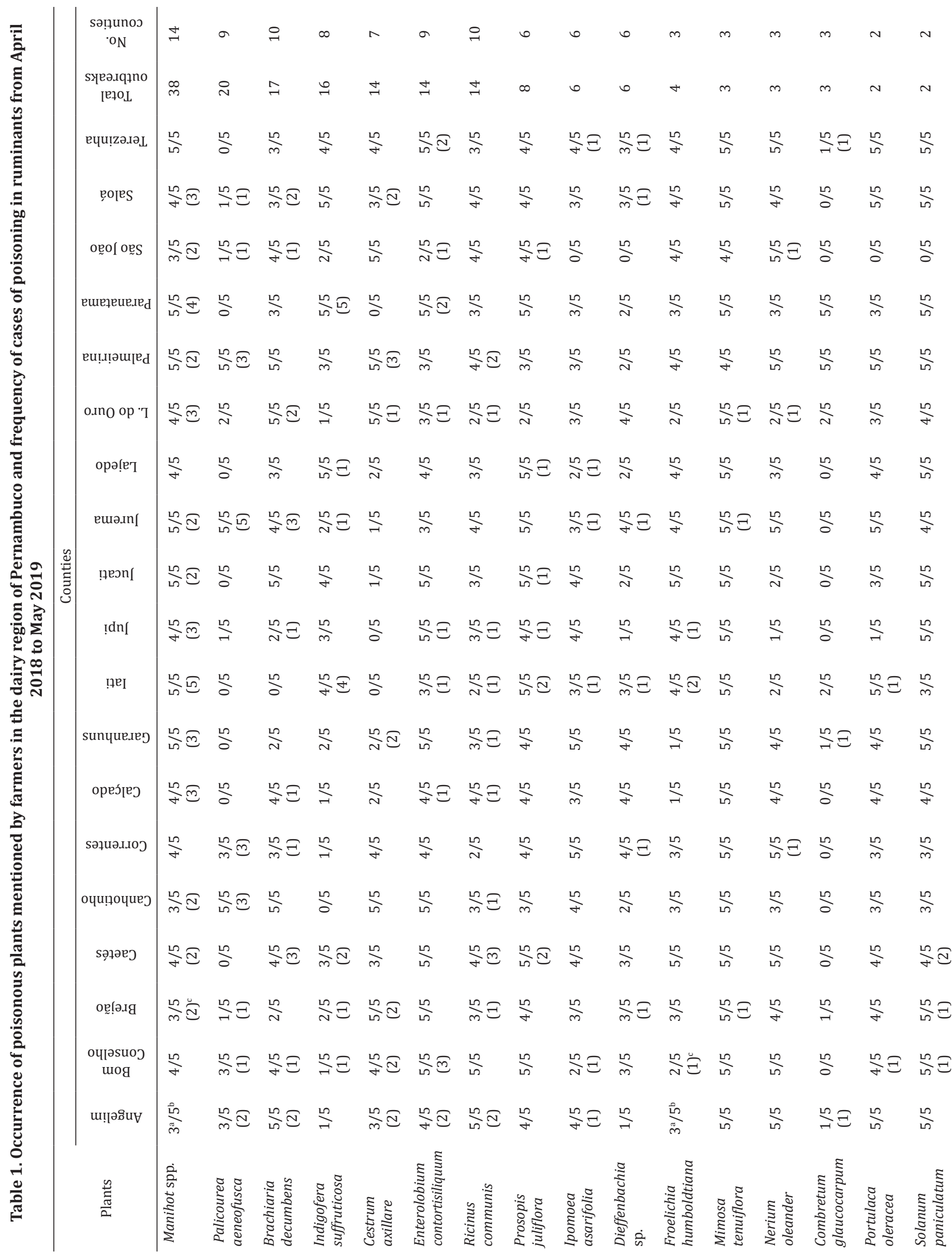




\begin{tabular}{|c|c|c|c|c|c|c|c|c|c|c|c|c|c|c|c|}
\hline $\begin{array}{l}\text { sə̣̣unos } \\
\text { oN }\end{array}$ & -1 & - & -1 & - & 0 & 0 & 0 & 0 & 0 & 0 & 0 & 0 & 0 & 0 & 0 \\
\hline $\begin{array}{c}\text { syеәлqдno } \\
\text { [еұоL }\end{array}$ & - & $-r$ & -1 & $-r$ & 0 & 0 & 0 & 0 & 0 & 0 & 0 & 0 & 0 & 0 & 0 \\
\hline еци!̣zə.əəЈ & $\frac{12}{12}$ & $\frac{\omega}{\omega n}$ & $\stackrel{n}{N}$ & $\frac{12}{12}$ & $\stackrel{n}{0}$ & $\frac{\omega}{n}$ & $\frac{10}{12}$ & $\stackrel{\llcorner}{N}$ & $\stackrel{20}{r}$ & $\stackrel{n}{-}$ & $\stackrel{n}{0}$ & $\stackrel{L}{\gamma}$ & $\stackrel{n}{0}$ & $\stackrel{2}{\gamma}$ & $\stackrel{L}{\gamma}$ \\
\hline exojes & $\frac{n}{m}$ & $\frac{10}{2 n}$ & $\frac{10}{20}$ & $\frac{12}{m}$ & $\stackrel{5}{f}$ & $\frac{n}{m}$ & $\frac{n}{m}$ & $\stackrel{10}{-1}$ & $\frac{10}{0}$ & $\stackrel{n}{\lambda}$ & $\stackrel{\text { Ln }}{7}$ & $\frac{n}{m}$ & $\stackrel{10}{7}$ & $\stackrel{n}{0}$ & $\frac{20}{2}$ \\
\hline ogol oess & $\stackrel{10}{0}$ & $\frac{10}{6 n}$ & $\stackrel{10}{0}$ & $\frac{10}{m}$ & $\overbrace{0}^{20}$ & $\stackrel{10}{7}$ & $\stackrel{10}{N}$ & $\stackrel{10}{0}$ & $\stackrel{20}{0}$ & $\stackrel{\text { L }}{0}$ & $\stackrel{\text { no }}{0}$ & $\stackrel{10}{0}$ & $\stackrel{10}{0}$ & $\stackrel{\text { L }}{0}$ & $\frac{10}{6 n}$ \\
\hline ешедеиеле $_{\mathrm{d}}$ & $\stackrel{2}{N}$ & $\frac{2}{2 n}$ & $\frac{12}{6}$ & $\frac{n}{m}$ & 응 & $\frac{\omega}{n}$ & $\frac{12}{12}$ & $\stackrel{2}{\rightarrow}$ & $\stackrel{2}{2}$ & $\stackrel{\text { L }}{0}$ & 造 & $\stackrel{\llcorner}{\gamma}$ & $\stackrel{2}{\sim}$ & 遂 & $\frac{n}{m}$ \\
\hline еи!̣ıәәшер & $\stackrel{2}{\rightarrow}$ & $\frac{12}{12}$ & $\stackrel{\llcorner}{ᄀ}$ & $\frac{12}{12}$ & $\stackrel{2}{0}$ & $\stackrel{2}{r}$ & $\stackrel{\llcorner}{\Rightarrow}$ & $\stackrel{2}{-2}$ & $\stackrel{20}{r}$ & $\stackrel{n}{N}$ & $\stackrel{12}{0}$ & $\frac{n}{m}$ & $\stackrel{\llcorner}{\rightarrow}$ & $\stackrel{\llcorner}{-1}$ & $\frac{2}{2}$ \\
\hline o.nо ор 'Т & $\stackrel{10}{0}$ & $\frac{10}{2 n}$ & $\stackrel{\llcorner}{\sim}$ & $\frac{10}{m}$ & $\stackrel{10}{0}$ & $\stackrel{\text { L }}{\rightarrow}$ & $\frac{10}{62}$ & $\stackrel{10}{0}$ & $\frac{10}{0}$ & $\stackrel{10}{0}$ & $\stackrel{10}{0}$ & $\stackrel{\operatorname{Ln}}{\mathrm{N}}$ & $\stackrel{n}{0}$ & $\stackrel{\llcorner}{-1}$ & $\frac{10}{0}$ \\
\hline орәฺ̣т & $\stackrel{2}{2}$ & $\frac{12}{n} \Xi$ & $\stackrel{2}{\gamma} \Xi$ & $\stackrel{\llcorner}{2}$ & $\stackrel{\text { no }}{\rightarrow}$ & $\frac{10}{7}$ & $\frac{10}{m}$ & $\stackrel{n}{i}$ & $\stackrel{n}{i}$ & $\stackrel{n}{0}$ & $\frac{10}{0}$ & $\stackrel{L}{2}$ & $\stackrel{10}{7}$ & $\stackrel{n}{0}$ & $\frac{10}{20}$ \\
\hline вшә.лn| & $\stackrel{n}{\sim}$ & $\frac{12}{12}$ & $\stackrel{\llcorner}{N}$ & $\frac{20}{6 n}$ & $\stackrel{\text { Ln }}{0}$ & $\frac{\omega}{m}$ & $\frac{12}{12}$ & $\stackrel{\sim}{N}$ & $\stackrel{\text { L }}{-1}$ & $\frac{\operatorname{Ln}}{2}$ & $\stackrel{\text { Ln }}{0}$ & $\stackrel{\llcorner}{-1}$ & $\stackrel{\llcorner}{\sim}$ & $\stackrel{n}{0}$ & $\frac{\omega}{20}$ \\
\hline !ุeวn| & $\stackrel{10}{2}$ & $\frac{10}{2 n}$ & $\frac{12}{2 n}$ & $\frac{20}{n}$ & $\frac{10}{0}$ & $\stackrel{L}{\gamma}$ & $\frac{10}{2 n}$ & $\stackrel{n}{-10}$ & $\frac{10}{0}$ & $\stackrel{n}{7}$ & $\frac{10}{0}$ & $\stackrel{\text { L }}{0}$ & $\frac{n}{0}$ & $\stackrel{n}{0}$ & $\frac{20}{2 n}$ \\
\hline Idnf & $\stackrel{n}{N}$ & $\frac{2}{12}$ & $\frac{12}{12}$ & $\frac{n}{m}$ & $\stackrel{n}{N}$ & $\frac{2}{n}$ & $\stackrel{\llcorner}{\gamma}$ & $\stackrel{n}{0}$ & $\stackrel{2}{-1}$ & $\stackrel{n}{N}$ & $\frac{10}{0}$ & $\frac{10}{n}$ & $\frac{n}{0}$ & $\stackrel{n}{0}$ & $\frac{12}{2}$ \\
\hline फ़ा I & $\stackrel{\sim}{\gamma} \Xi$ & $\frac{12}{20}$ & $\stackrel{L}{\gamma}$ & $\stackrel{\llcorner}{N}$ & $\stackrel{n}{N}$ & $\frac{\omega n}{n}$ & $\frac{n}{m}$ & $\stackrel{2}{0}$ & $\stackrel{\llcorner 2}{-}$ & $\stackrel{\llcorner}{0}$ & $\stackrel{12}{0}$ & $\stackrel{\llcorner}{\Rightarrow}$ & $\stackrel{\llcorner}{\sim}$ & $\frac{n}{m}$ & $\stackrel{\llcorner}{\gamma}$ \\
\hline sunquexey & $\stackrel{20}{2}$ & $\frac{12}{62}$ & $\frac{12}{m}$ & $\stackrel{\llcorner}{2}$ & $\frac{n}{m}$ & $\stackrel{n}{\circ}$ & $\frac{12}{7}$ & $\stackrel{10}{-1}$ & $\stackrel{10}{0}$ & $\stackrel{n}{N}$ & $\varliminf_{0}^{20}$ & $\stackrel{10}{0}$ & $\stackrel{10}{\rightarrow}$ & $\stackrel{10}{0}$ & $\stackrel{n}{\sim}$ \\
\hline ореб́ґе] & $\stackrel{n}{2}$ & $\frac{n}{n}$ & $\stackrel{n}{N}$ & $\stackrel{\llcorner}{\not}$ & $\stackrel{n}{N}$ & $\stackrel{\llcorner}{\gamma}$ & $\stackrel{\llcorner}{٪}$ & $\stackrel{\text { L }}{-}$ & $\stackrel{12}{0}$ & $\stackrel{\llcorner}{\rightarrow}$ & $\stackrel{n}{0}$ & $\stackrel{2}{0}$ & $\stackrel{\text { L }}{7}$ & $\stackrel{\sim 2}{-}$ & $\frac{12}{m}$ \\
\hline ธәһนว...0ว & $\stackrel{10}{0}$ & $\frac{10}{12}$ & $\frac{10}{m}$ & $\frac{12}{12}$ & $\stackrel{n}{N}$ & $\stackrel{\llcorner}{0}$ & $\stackrel{\llcorner 2}{\gamma}$ & $\stackrel{\llcorner}{-1}$ & $\stackrel{\llcorner}{-1}$ & $\stackrel{n}{0}$ & $\stackrel{n}{0}$ & $\frac{\omega}{m}$ & $\stackrel{\llcorner}{0}$ & $\stackrel{2}{\rightarrow}$ & $\stackrel{2}{0}$ \\
\hline очиฺрочиет & $\stackrel{10}{0}$ & $\frac{12}{12}$ & $\stackrel{10}{0}$ & $\stackrel{\sim}{\sim}$ & $\stackrel{\text { Ln }}{0}$ & $\stackrel{\text { L }}{\rightarrow}$ & $\stackrel{\llcorner 2}{\gamma}$ & $\stackrel{\llcorner}{0}$ & $\stackrel{\sim}{\sim}$ & $\stackrel{10}{0}$ & $\stackrel{\text { Ln }}{0}$ & $\stackrel{\llcorner}{0}$ & $\stackrel{\llcorner}{2}$ & $\stackrel{\llcorner}{\rightarrow}$ & $\frac{\omega}{m}$ \\
\hline 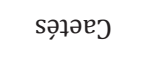 & $\frac{n}{m}$ & $\frac{2}{12}$ & $\stackrel{2}{\gamma}$ & $\frac{n}{m}$ & $\stackrel{n}{N}$ & $\stackrel{\llcorner}{\Rightarrow}$ & $\frac{12}{6}$ & $\stackrel{\llcorner}{0}$ & $\stackrel{\infty}{\sim}$ & $\stackrel{\llcorner}{\rightarrow}$ & $\stackrel{n}{0}$ & $\stackrel{\llcorner}{0}$ & $\stackrel{2}{0}$ & $\stackrel{\llcorner}{\rightarrow}$ & $\frac{2}{2 n}$ \\
\hline 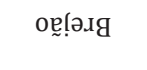 & $\stackrel{20}{7}$ & $\frac{n}{2 n}$ & $\stackrel{n}{\lambda}$ & $\frac{n}{n} \Xi$ & $\stackrel{\operatorname{Ln}}{\rightarrow}$ & $\stackrel{n}{\sim}$ & $\frac{n}{m}$ & $\stackrel{2}{\sim}$ & L & $\stackrel{n}{\rightarrow}$ & $\stackrel{n}{\rightarrow}$ & $\stackrel{\text { L }}{\rightarrow}$ & $\stackrel{\text { L }}{\rightarrow}$ & $\stackrel{2}{\stackrel{2}{7}}$ & $\frac{10}{20}$ \\
\hline $\begin{array}{l}\text { очाəsuoJ } \\
\text { шоg }\end{array}$ & $\frac{10}{0}$ & $\frac{n}{\omega}$ & $\frac{n}{n}$ & $\frac{n}{n}$ & $\frac{10}{n}$ & $\frac{\omega}{\omega}$ & $\frac{12}{n}$ & $\stackrel{\text { L }}{0}$ & $\stackrel{n}{-1}$ & $\stackrel{n}{0}$ & $\stackrel{n}{0}$ & $\stackrel{10}{2}$ & 造 & $\stackrel{\llcorner}{0}$ & $\frac{n}{n}$ \\
\hline ய!̣วฉిu & $\stackrel{n}{\sim}$ & $\frac{10}{20}$ & $\stackrel{n}{0}$ & $\frac{10}{20}$ & $\frac{\text { ํำ }}{8}$ & $\stackrel{n}{\circ}$ & $\stackrel{12}{2}$ & $\stackrel{10}{0}$ & $\stackrel{n}{0}$ & $\stackrel{\ln }{0}$ & $\stackrel{\text { Ln }}{0}$ & $\stackrel{10}{-1}$ & $\frac{10}{0}$ & $\stackrel{n}{0}$ & $\frac{10}{2}$ \\
\hline $\begin{array}{l}\frac{\tilde{n}}{\frac{\pi}{0}} \\
\frac{\pi}{2}\end{array}$ & 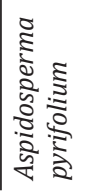 & 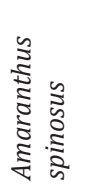 & 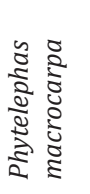 & 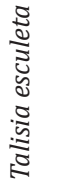 & 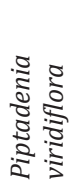 & : & 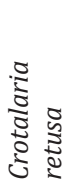 & 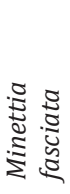 & 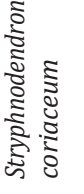 & 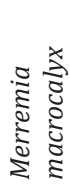 & 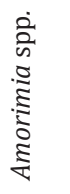 & 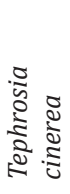 & 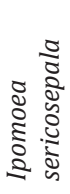 & 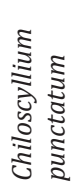 & 气ี \\
\hline
\end{tabular}


and Saloá. However, no histories of poisonings were reported, and our team did not find this species during technical visits.

Cardiotoxic plants. Palicourea aeneofusca (Rubiaceae) was recognized by twenty-nine $(29 / 95,30.52 \%)$ farmers in 11 municipalities, exclusively on those farms which have maintained their forests. Twenty outbreaks $(20 / 178$, $11.23 \%$ ) of sudden death associated with the consumption of $P$. aneofusca were reported affecting 53 cattle and our team found moderate amounts of this plant in the farms. No cases of poisoning were reported affecting sheep or goats. The interviewees reported presumptive diagnosis based on acute clinical signs, after cattle have access to Atlantic Forests areas and by the observation of leaves with evidence to be consumed by the herds. According to the owners, commonly, cattle were found fallen and died after being forced to move. Outbreaks of poisoning by $P$. aeneofusca occurred in the municipalities of Angelim, Bom Conselho, Brejão, Canhotinho, Correntes, Jurema, Palmeirina, São João and Saloá.

Nerium oleander (Apocynaceae) was recognized by seventytwo farmers $(72 / 95,75.78 \%)$ as ornamental plants of gardens and squares. Three farmers $(3 / 178,1.78 \%)$ claimed to have witnessed cases of poisoning in their properties. A farmer from the municipality of São João reported the death of two working oxen, after tying them to a fence near to $N$. oleander. These oxen ingested the plant and died when placed to walk back to the farm. In another report, the farmer mentioned the mortality of 2 goats that ingested the withered leaves of oleander after pruning. The goats died 8 hours after ingestion.

Amorimia spp. (Malpighiaceae) was mentioned only by one farmer who knew the plant; however, no cases of poisoning were mentioned. During technical visits, Amorimia spp. was not found.

Plants that affect the digestive system. Enterolobium contortisiliquum (Leg. Mimosoideae) was recognized as toxic by eighty farmers $(80 / 95,84.31 \%)$ and fourteen outbreaks of poisonings were reported $(14 / 178,7.86 \%)$ affecting 37 cattle in the total. The clinical signs reported by farmers included digestive disease, abortions, and photosensitization. One farmer mentioned the development of bloat and diarrhea in four cattle and, severe photosensitization, after the tree was cut down and cattle ingested leaves and pods of $E$. contortisiliquum. Outbreaks of poisoning were reported in Bom Conselho, Angelim, Terezinha, Paranatama, São João, Calçado, Jupi, Iati and Lagoa do Ouro.

Dieffenbachia picta (Araceae), an ornamental plant, was recognized by forty-nine farmers $(49 / 95,51.57 \%)$ that said this plant is poisonous. Six outbreaks (6/178, 3.37\%) affecting a total 3 cattle, one sheep and three goats were reported. The clinical picture, in general, was mild and consisted of salivation, submandibular edema and tongue protrusion. All the animals recovered totally after five days after the observation of the first clinical signs.

Centratherum punctatum (Asteraceae) was recognized by fourteen farmers $(14 / 95,14.73 \%)$, who reported the existence of the plant and stated that its occurrence in the pasture areas decreased significantly, after the drought episodes in the region. The plant was not found, and no cases of poisoning were reported.

Stryphnodendron coriaceum (Leg. Mimosoideae) was mentioned by fourteen farmers (14/95, 14.73\%), but they were unaware of its toxicity and used it as a herbal medicine. During inspection of pastures in the municipalities, the plant was not found. There was no report of poisoning associated with this plant.
Merremia macrocalyx (Convolvulaceae) was recognized by seventeen farmers $(17 / 95,17.89 \%)$ that reported that they knew the plant and that it sprouts soon after the first rains, however, they did not report cases of poisonings.

Plants that cause photosensitivity. According to farmers, the main plant causing photosensitization in the dairy region of Pernambuco is Brachiaria decumbens (Poaceae). This grass is widely used in the farms in pasture areas of cattle and sheep and it was found in 70.52\% (67/95) of the farms visited. Seventeen outbreaks of poisoning were accounted for in the region $(17 / 178,9.55 \%)$. Brachiaria decumbens was reported as the cause of severe dermatitis in thirty-two cattle and sixteen sheep; most of them were acquired from the semiarid region of Pernambuo, where this grass is not used frequently. Affected cattle and sheep showed severe skin lesions, consisting of necrosis of the skin mainly in the depigmented areas. In more than half of the municipalities visited, 52.63\% (10/19), the occurrence of at least one outbreak of poisoning was mentioned. The municipalities where outbreaks were reported were São João, Angelim, Calçado, Caetés, Jupi, Jurema, Saloá, Bom Conselho, Lagoa do Ouro and Correntes.

Froelichia humboldtiana (Amaranthaceae), a plant that causes primary photosensitization, was recognized by sixty-three farmers $(63 / 95 ; 66.31 \%)$ that stated that $F$. humboldtiana is widely distributed throughout the dairy region of Pernambuco. Four outbreaks of poisoning (4/178; $2.24 \%$ ) were reported in Jupi, Bom Conselho and Iati. In the total 10 sheep and 2 cattle presented severe itching and skin necrosis and recovered 18 days after they were removed from the pasture infested by $F$. humboldtiana.

Lantana camara (Verbenaceae) was also found in all municipalities visited in the region, but just in small amounts and not invading pasture areas. This species was recognized by seventy-one farmers $(71 / 95 ; 74.73 \%)$, but they did not associate it with cases of poisonings in ruminants.

Another plant causing primary photosensitization, Malachra fasciata, is found in the region and was recognized by sixteen farmers $(16 / 95 ; 16.84 \%)$ which answered that $M$. fasciata is found in flooded areas and it is not common to see it in the pasture areas. Our team did not find $M$. fasciata in the region and no cases of poisoning were reported.

Plants that cause hemolytic anemia. Indigofera suffruticosa (Leg. Papilionoideae) is the only poisonous plant that causes hemolytic anemia found in the dairy region of Pernambuco. Forty-nine farmers $(49 / 95,51.57 \%)$ recognized I. suffruticosa as toxic and mentioned its occurrence. Sixteen outbreaks were reported $(16 / 178,8.98 \%)$ and all cases occurred in cattle. Reports of cattle urinating blood after grazing infested areas with I. suffruticosa occurred in the municipalities of Paranatama, Iati, Caetés, Conselho, Lajedo, Jurema, Terezinha and Brejão. In a total, 39 cattle were severely affected and died five to eight days after the observation of the first clinical signs.

Hepatotoxic plants. Three hepatotoxic plants of economic importance are found in the region studied: Cestrum axillare (Solanacea), Crotalaria retusa (Fabaceae) and Tephrosia cinerea (Fabaceae).

Cestrum axillare was reported by fifty-four producers $(54 / 95,56.84 \%)$ who knew the plant and reported fourteen outbreaks of poisoning $(14 / 178,7.86 \%)$. The municipalities where cases of poisoning were reported were Palmeirina, 
Angelim, Saloá, Bom Conselho, Garanhuns, Brejão and Lagoa do Ouro. In the municipality of Brejão, two cattle died after consuming the plant that was pruned and displaced in an area close to the corral, allowing the animals access. These cattle showed clinical signs of drooling, apathy, antialgic position and muscle tremors dying 2 days after the observation of the first clinical signs.

Crotalaria retusa was mentioned by seventy-seven farms $(77 / 95,81.05 \%)$ who reported its occurrence in the region and Tephrosia cinerea by thirty-six farmers (36/95, 37.89\%). However, no cases of poisoning were reported.

Nephrotoxic plants. Two species of nephrotoxic plants were registered, being Amaranthus spinosus widespread in the region in large amount, and Combretum glaucocarpum (= Thiloa glaucocarpa), that were found by our team in Angelim, Garanhuns, Terezinha, Bom Conselho, Brejão, Caetés, Calçado and Canhotinho. Its occurrence was reported by eighteen farmers $(18 / 95,18.94 \%)$. Three cases of poisoning were mentioned in the municipalities of Terezinha, Garanhuns and Angelim, which corresponds to $1.68 \%(3 / 178)$ of the frequency of intoxication outbreaks. A farmer from the municipality of Angelim planted C. glaucocarpum to use the wood for making fences. Five cattle had access to this area when the plant was growing up and presented clinical signs consisting of subcutaneous edema, mainly in dewlap, ventral portion of the thorax and the hindlimbs dying after three weeks after the observation of the first clinical signs. In Terezinha, 4 cattle died after having access to the leaves of the plant that were pruned to make a fence in the farm. The clinical pictures were similar to the described above.

Amaranthus spinosus (Amaranthaceae) was found in all the municipalities visited, but despite its large presence, A. spinosus was associated with one outbreak of poisoning $(1 / 178 ; 0.56 \%)$ that affected eight cattle grazing in a pasture area severely infested by this plant. The cattle presented clinical signs mainly characterized by edema of the dewlap and the limbs. Five cattle died and three recovered after being removed from the pasture infested.

Plants affecting the reproductive system. Three species of plants causing fetal malformation and abortions are found in the dairy region of Pernambuco: Mimosa tenuiflora, Aspidosperma pyrifoliumm and Poincianella pyramidalis.

Mimosa tenuiflora (Leg. Mimosoideae) is largely found in the region, being observed in ninety-three farms visited $(93 / 95 ; 97.89 \%)$. Its toxicity is unknown by most farmers. Three farmers $(3 / 178,1.68 \%)$ reported the occurrence of malformations in cattle, sheep, and goats in the municipalities Jurema, Lagoa do Ouro and Brejão. The farmers noticed an increased rate of animals born with malformations and an increase in abortion cases. The main malformations reported were microphthalmia and arthrogryposis.

Aspidosperma pyrifolium (Apocynaceae) was recognized by thirty-two farmers $(32 / 95,33.68 \%)$ that said they knew the plant, as well as citing the occurrence in their pastures. One farmer from the municipality of Iati $(1 / 178,0.56 \%)$ reported the occurrence of one cow that gave birth of a premature calf and other that aborted after being placed in an area with large amounts of $A$. pyrifolium. These cows consumed the leaves mainly due to the scarcity of forages during the dry season.

Poincianella pyramidalis (Fabaceae) was recognized by fifty-three farmers $(53 / 95,55.78 \%)$ in 16 municipalities.
They mentioned the existence of $P$. pyramidalis, however, there was no report of outbreaks of poisonings associated with reproductive problems. According to the farmers, $P$. pyramidalis is not palatable and is avoided by cattle and sheep, being sporadically consumed by goats during the dry season, when food supplies are scarce.

Oxalate-containing plants. Portulaca oleracea (Portulacaceae) was recognized by sixty-nine farmers (69/95, $72.63 \%$ ) that reported the occurrence of this plant in pasture areas, especially near the corral but in small amounts. In the rainy season some farmers collect $P$. oleracea to use as food supply for cattle, sheep, and goats. Two outbreaks of poisoning $(2 / 178,1.12 \%)$ affecting 12 cattle in a total were reported. Most cases were observed affecting calves and but also in four adult animals. All calves and two adult cattle died after presenting severe bloat, diarrhea, and sternal recumbency. Two cattle recovered eight days after the supply of the plant was interrupted. These outbreaks occurred in the municipalities of Bom Conselho and Iati.

\section{Plants not reported in the literature as poisonous but needs investigation}

Psychotria spp. Three plants from the Rubiaceae family, Psychotria hoffmannseggiana (Fig.4), Psychotria colorata (Fig.5) and Psychotria capitata (Fig.6) were reported by the farmers as the cause of sudden death in cattle in the dairy region of Pernambuco.

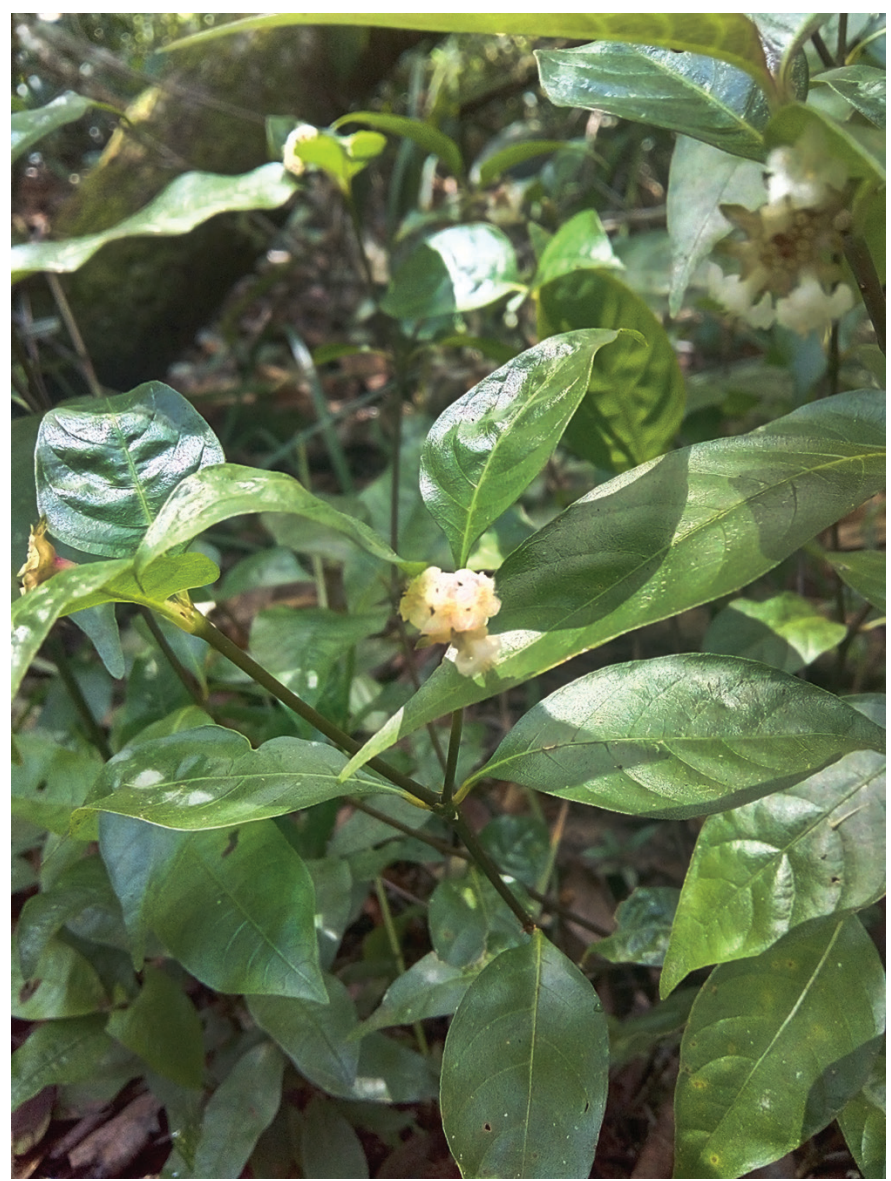

Fig.4. Psychotria hoffmannseggiana in the municipality of Canhotinho, Pernambuco State, Brazil. 
Psychotria hoffmannseggiana (rat weed) was reported as responsible for one outbreak affecting cattle that resulted in the death of five cows. The clinical picture was acute and consisted of gait instability, muscular tremors, and death after being forced to move. P. hoffmannseggiana was found in the municipalities of Jurema and Canhotinho. Psychotria colorata and Psychotria capitata (white-flower rat weed) were also reported as toxic for cattle. Seven farmers (7/95; $7.36 \%$ ) stated that $P$. capitata causes death in cattle and the clinical histories for these two Rubiaceae were the same and included gait instability, muscular tremors and deaths after the cattle being forced to move. On those farms visited, in which Psychotria spp. was present, our team was not able to find species of Palicourea.

\section{DISCUSSION}

This is the first large study carried out in the most important livestock farming region in the State of Pernambuco, and the information acquired through the farmers associated with field investigations, allowed to obtain important data concerning epidemiology and some particularities about poisonings caused by plants in ruminants in this region. Cyanogenic, neurotoxic and cardiotoxic plants, followed by plants that cause photosensitization and plants that affect the digestive system are the most frequent classes of poisonous plants associated with outbreaks of poisonings in ruminants. The

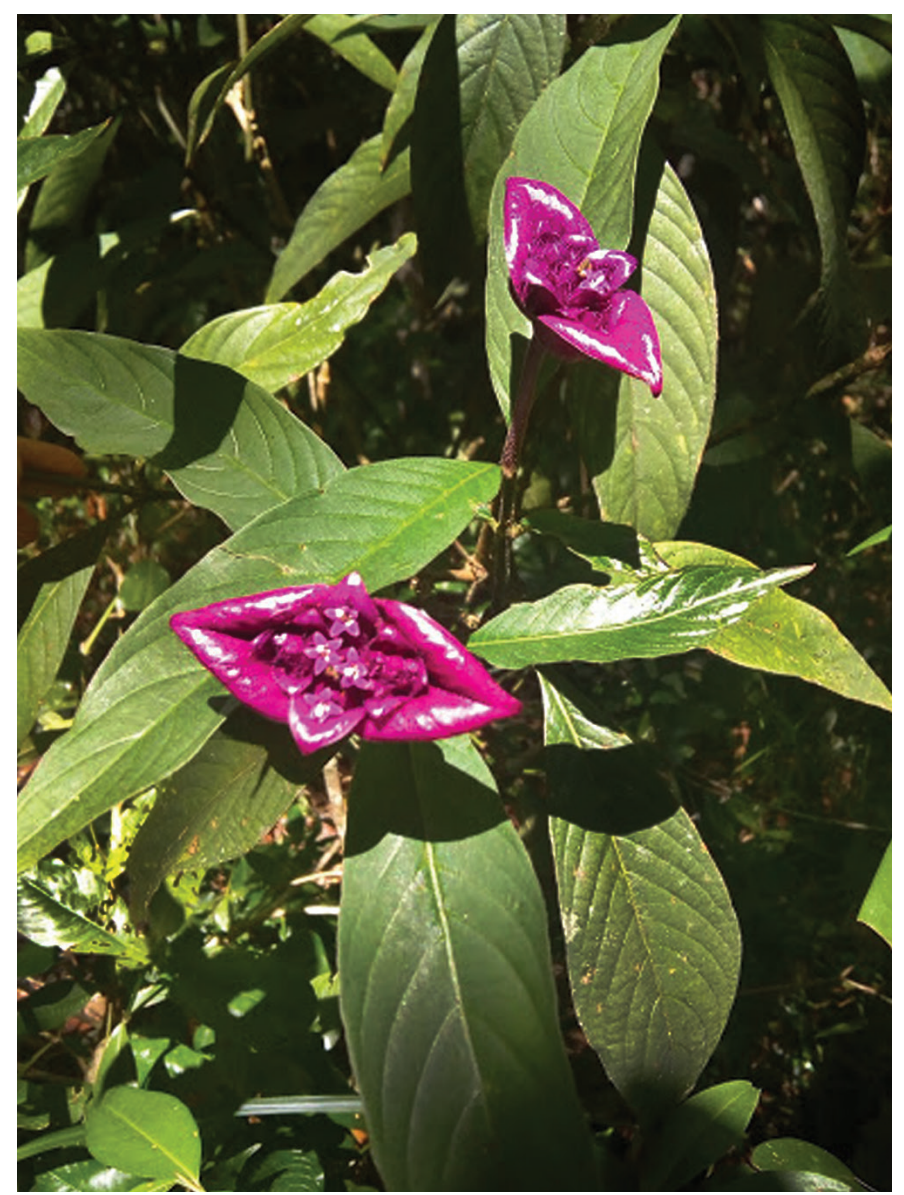

Fig.5. Psychotria colorata in the municipality of Garanhuns, Pernambuco State, Brazil. most important species of plants associated with outbreaks of poisonings were Manihot esculenta, Palicourea aeneofusca, Brachiaria decumbens, followed by Indigofera suffruticosa, Ricinus communis and Cestrum axillare. Additionally, the reports given by farmers raise the hypothesis related to the toxic properties of Psychotria spp. for cattle.

Reports of poisonings in cattle, sheep and goats caused by Manihot esculenta corresponded to almost half of the deaths caused by poisonous plants reported in this study. The dairy region of Pernambuco produces the major proportion of cassava in the State, with a total area of planting of 27.789 ha, and most part of it is produced by small farmers that benefits the roots of $M$. esculenta in cassava flour for human consumption (IBGE 2017). These poisonings occur because ruminants frequently have access to cassava's wastewater (a by-product for cassava flour production) or to the cassava's bark, that are used as animal feed. Poisonings also occur when ruminants invade areas of $M$. esculenta during the dry season, when they are starving due to the scarcity of pastures. Other cyanogenic plants, such as $P$. macrocarpa and $P$. viridiflora occur in the region, but outbreaks of poisoning in ruminants are not frequent.

Palicourea aeneofusca, a plant that causes sudden death in ruminants, was alone responsible for $16 \%$ of the total of outbreaks reported. This plant remains as one of the most important causes of deaths caused by poisonous plants

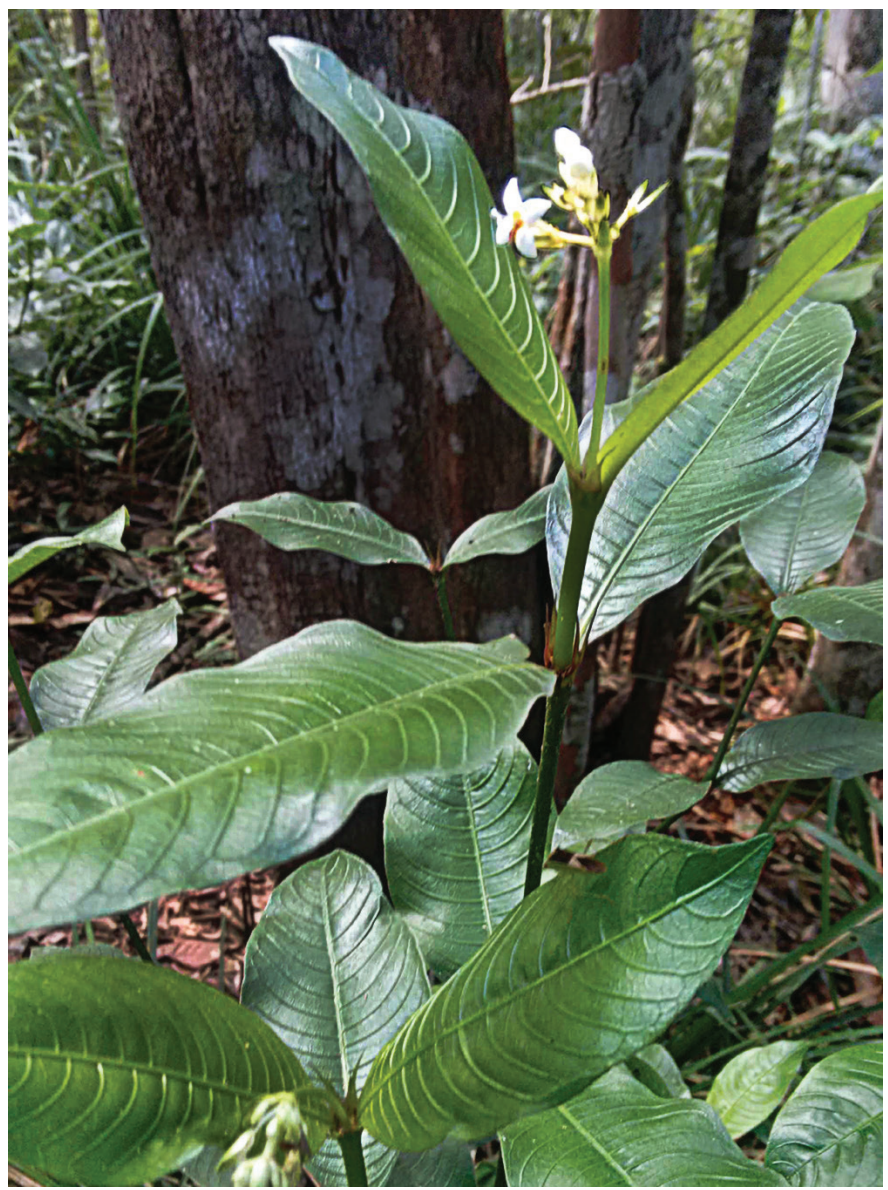

Fig.6. Psychotria capitata in the municipality of Garanhuns, Pernambuco State, Brazil. 
of cattle in the region, due to its frequent occurrence in the farms, good palatability and to the high levels of toxic monofluoroacetate (MFA), as reported previously (Lee et al. 2012, Cook et al. 2014, Brito et al. 2016). Nerium oleander, a glycoside cardiotoxic containing plant (Armién et al. 1994) was also mentioned, but this plant is less important because the poisonings are only accidental and sporadic (Soto-Blanco et al. 2006, Pedroso et al. 2009, Ceci et al. 2020). Other causes of sudden death of cattle in the region were associated with poisonings by species of Psychotria.

The Psychotria taxa are closely related to Palicourea species and its classification is problematic, with some species currently classified in Psychotria are more closely related to Palicourea (Taylor 1996, Taylor et al. 2010, Taylor \& Gereau 2013, Cook et al. 2014). Until to date, MFA was only detected in P. hoffmannseggiana (Pedroza 2015), while in several species, such as Psychotria alba, Psychotria deflexa, Psychotria fastigiata, Psychotria gracilenta and Psychotria officinalis, MFA was not detected. These same variations occur in species of Palicourea, wherein several species do not have MFA (Cook et al. 2014).

In our experience, most cases in which Psychotria spp. is blamed to cause cattle death, the real cause is Palicourea spp. However, it is known that species of Psychotria are rich sources of alkaloids (indoles, monoterpene indoles, quinoline and isoquinoline) as well as flavonoids, coumarins, terpenoids and cyclic peptides that might be responsible for a wide range of biological activities. For example, $P$. hoffmannseggiana and P. capitata extracts (leaves or stems) are significantly toxic for insects and the alkaloid fraction from the ethanol extracts of flowers and leaves of $P$. colorata have opioidergic effects in rats; while $P$. ipecacuanha, which contain the isoquinoline alkaloid emetine, has emetic effect and also cause muscle weakening and cardiac damage (Matsuura et al. 2013, Calixto et al. 2016). Due to this wide variety of compounds in Psychotria spp. and due the absence of species of Palicourea in some farms visited at the dairy region of Pernambuco, the importance of Psychotria spp. as the cause of poisonings in cattle should be better investigated.

The main poisonous plant affecting the digestive system of ruminants found in the dairy region of Pernambuco was E. contortisiliquum. This plant is commonly found in grazing areas and the pods are easily consumed by cattle and less frequently by sheep, and goats when found on the ground. These poisonings occur mainly between May to September, when the plant is in the fruitification period, which coincides with the dry season and reduction of disponible pastures in Northeastern Brazil (Grecco et al. 2002, Mendonça et al. 2009, Olinda et al. 2015). However, despite the digestive disease and abortifacient properties associated with the consumption of E. contortisiliquum pods in ruminants, the main clinical sign reported by farmers in this study was photosensitization.

Plants that cause photosensitization were the fourth class of poisonous plants in order of importance found in this study. Of these, $B$. decumbens was the third most important cause of deaths of cattle reported by farmers. In our experience, this is not a usual rate because, generally, the mortality associated with $B$. decumbens in herds is not high (Silva et al. 2006, Mello et al. 2010, Nascimento et al. 2018). This elevated rate can be attributed to errors of judgment of farmers, because the clinical and pathologic picture caused by
B. decumbens is similar to those observed in the poisonings caused by E. contortisiliquum and Cestrum axillare, other two very important poisonous plants associated with poisonings, photosensitization and death of ruminants in the region. However, some reasons make $B$. decumbens an important plant in this study: 1 . This grass is largely used by farmers in the pasture areas of cattle and sheep; 2 . Most of herds are of Holstein cows, or crossbred of Holstein and Jersey (breeds which have several parts of white skin and are more sensible than zebu) and 3. The frequent introduction of naive animals from the semiarid region of Pernambuco (Costa et al. 2011, Faccin et al. 2014, Nascimento et al. 2018). It is also important to remember that sheep are more sensible to poisonings by saponins contained in B. decumbens (Lemos et al. 1996, Macedo et al. 2008, Ogliari et al. 2018).

Froelichia humboldtiana, a plant that causes primary photosensitization in cattle, sheep and goats (Souza et al. 2012, Knupp et al. 2018, Silva Filho et al. 2020) was frequently found in the region, however, few outbreaks of poisonings were reported (four outbreaks in total). This low number of cases probably occurred because $F$. humboldtiana is less recognized by farmers and veterinarians as the etiology of photodermatitis in ruminants. Despite this, during the inspection of the grazing areas, $F$. humboldtiana was found in large amounts, mainly after the first rains and when the famers did not take care of pastures.

Indigofera suffruticosa was another poisonous plant frequently reported as important, mainly in the municipality of Paranatama. This plant was associated with outbreaks of poisoning in cattle with clinical signs of hemoglobinuria that evolved to death. Despite this frequency, the farmers know that I. suffruticosa is poisonous for cattle and avoid placing herds in grazing areas with large amounts of this plant. $I$. suffruticosa is frequently reported as an important cause of cattle poisonings in other regions of Northeastern Brazil (Barbosa Neto et al. 2001, Silva et al. 2006, Assis et al. 2009, Mello et al. 2010, Figueiredo et al. 2012, Pedroso et al. 2018).

The class of neurotoxic plants is represented by several different species of poisonous plants in the dairy region of Pernambuco. Despite its high occurrence and the high number of outbreaks of poisonings reported, most cases associated with the consumption of $R$. communis, I. asarifolia and $S$. paniculatum were non-fatal. These plants and P. juliflora are the four main neurotoxic plants found in the dairy region of Pernambuco. Poisonings caused by the ingestion of R. communis leaves, mainly by cattle, occurred with high frequency because of scarcity of food due to a severe drought from 2013 to 2018 in the region. This same situation was reported previously affecting cattle in the semiarid region of Paraíba (Assis et al. 2009, Albuquerque et al. 2014). Poisonings by I. asarifolia are frequently reported in North and Northeastern Brazil (Barbosa et al. 2005, 2006, Oliveira et al. 2009, Carvalho et al. 2014, Mendonça et al. 2018) and until to date, the poisoning by $S$. paniculatum was just reported in cattle the dairy region of Pernambuco (Guaraná et al. 2011).

Despite previous years of drought, only five reports of poisoning in cattle caused by P. juliflora was obtained in this study. This low frequency of outbreaks may be explained by the fact that drought season in the dairy region of Pernambuco is not severe as in the Sertão, where ruminants had free access to areas heavily invaded by P. juliflora. This same epidemiological 
situation occurs in other States, where the Caatinga biome is being degraded and invaded by mesquite (Mendonça et al. 2020). Additionally, farmers generally know that $P$. juliflora is toxic when used excessively for cattle and goats and for this reason, they use less than $50 \%$ of mesquite beans in the composition of cattle and goats' diets. These animals are also sent frequently to the slaughterhouse when present loss of the condition due to the poisoning by P. juliflora. Maybe because of these reasons, clinical pictures were not often observed.

Cestrum axillare was the fifth most important plant for cattle in the dairy region of Pernambuco and some reports were previously published in the literature affecting a significant number of cattle (Silva \& Silva Júnior 1996, Coutinho et al. 2013). C. axillare is unpalatable for ruminants and is just eaten in situations of hunger (Brito et al. 2010, Coutinho et al. 2013, Marinho et al. 2018). During the dry season, the dairy region of Pernambuco receives a large traffic of herds coming from farms located in the semiarid region of the State and most cases associated with the poisoning by $C$. axillare occur during time: when cattle are tired, thirsty, starved and find the green leaves of this plant near to the corrals, fences and forest borders. This peculiarity is probably the main cause for the occurrence of these poisonings.

Less important classes of poisonous plants in the dairy region of Pernambuco included nephrotoxic plants, oxalate-containing plants and plants that cause abortions or malformations.

\section{CONCLUSION}

Based on the data reported and field investigations, we can conclude that Manihot esculenta and Palicourea aeneofusca are the two major poisonous plants for ruminants found in the dairy region of Pernambuco. On another hand, Psychotria hoffmannseggiana, Psychotria colorata and Psychotria capitata should be better investigated to evaluate their importance as the cause of cattle deaths.

Acknowledgments.- To the "Coordenação de Aperfeiçoamento de Pessoal de Nível Superior" (CAPES), Finance Code 001, and "Conselho Nacional de Desenvolvimento Científico e Tecnológico" (CNPq), Process 304804/2018-5, for granting the necessary financial support for the development of this study.

Conflict of interest statement.- The authors declare no conflicts of interest.

\section{REFERENCES}

Albuquerque S.S.C., Rocha B.P., Albuquerque R.F., Oliveira J.S., Medeiros R.M.T., Riet-Correa F., Evêncio-Neto J. \& Mendonça F.S. 2014. Spontaneous poisoning by Ricinus communis (Euphorbiaceae) in cattle. Pesq. Vet. Bras. 34(9):827-831. <https://dx.doi.org/10.1590/S0100-736X2014000900004>

Almeida V.M., Rocha B.P., Pfister J.A., Medeiros R.M.T., Riet-Correa F., Chaves H.A.S, Silva Filho G.B. \& Mendonça F.S. 2017. Spontaneous poisoning by Prosopis juliflora (Leguminosae) in sheep. Pesq. Vet. Bras. 37(2):110- 114 <https://dx.doi.org/10.1590/s0100-736x2017000200003>

Andrade Neto A.Q., Souza J.C.A., Mendonça C.L., Riet-Correa F., Melo-Neto G.B., Cajueiro J.F.P \& Afonso J.A.B. 2016. Intoxicação natural por Amaranthus spinosus (Amaranthaceae) em bovinos no Agreste do estado de Pernambuco. Ciênc. Vet. Tróp. 19(1):3139.

Armién A.G., Peixoto P.V., Barbosa J.D. \& Tokarnia C.H. 1994. Intoxicação experimental por Nerium oleander (Apocinaceae) em ovinos. Pesq. Vet. Bras. 14(2/3):85-93

Assis T.D., Medeiros R.M.T., Araújo J.A.S., Dantas A.F.M. \& Riet-Correa F. 2009. Intoxicações por plantas em ruminantes e equídeos no Sertão Paraíbano.
Pesq. Vet. Bras. 29(11):919-924. <https://dx.doi.org/10.1590/S0100736X2009001100010>

Barbosa J.D., Oliveira C.M.C., Duarte M.D., Peixoto P.V. \& Tokarnia C.H. 2005. Intoxicação experimental e natural por Ipomoea asarifolia (Convolvulaceae) em búfalos e outros ruminantes. Pesq. Vet. Bras. 25(4):231-234. <https://dx.doi.org/10.1590/S0100-736X2005000400008>

Barbosa Neto J.D., Oliveira C.M.C., Peixoto P.V., Barbosa I.B.P., Ávila S.C. \& Tokarnia C.H. 2001. Anemia hemolítica causada por Indigofera suffruticosa (Leg. Papilionoideae) em bovinos. Pesq. Vet. Bras. 21(1):18-22. <https://dx.doi.org/10.1590/S0100-736X2001000100005>

Barbosa R.C., Riet-Correa F., Medeiros R.M.T., Lima E.F., Barros S.S., Gimeno E.J., Molyneux R.J. \& Gardner D.R. 2006. Intoxication by Ipomoea sericophylla and Ipomoea riedelii in goats in the state of Paraíba, Northeastern Brazil. Toxicon 47(4):371-379. <https://dx.doi.org/10.1016/j.toxicon.2005.11.010> <PMid:16488457>

Brito L.B.D., Albuquerque R.F., Rocha B.P., Albuquerque S.S., Lee S.T., Medeiros R.M.T., Riet-Correa F. \& Mendonça F.D.S. 2016. Spontaneous and experimental poisoning of cattle by Palicourea aeneofusca in the region of Pernambuco and induction of conditioned food aversion. Ciência Rural 46(1):138-143. <https://dx.doi.org/10.1590/0103-8478cr20150079>

Brito M.F., França T.N., Oliveira L.I., Ramos A.S., Peixoto T.C \& Aragão A.P. 2010. Intoxicação espontânea por Cestrum laevigatum em um caprino no Rio de Janeiro-relato de caso. Revta Bras. Med. Vet. 32(1):55-57.

Calixto N.O., Pinto M.E.F., Ramalho S.D., Burger M.C.M., Bobey A.F., Young M.C.M., Bolzani V.S. \& Pinto A.C. 2016. The genus Psychotria: phytochemistry, chemotaxonomy, ethnopharmacology and biological properties. J. Braz. Chem. Soc. 27(8):1355-1378. <https://dx.doi.org/10.5935/0103-5053.20160149>

Carvalho L.K.F., Dantas A.F.M., Riet-Correa F., Pires J.P.S. \& Silva F.O.R. 2014. Intoxicação por Ipomoea asarifolia em bovinos e ovinos no Rio Grande do Norte. Pesq. Vet. Bras. 34(11):1073-1076. <https://dx.doi.org/10.1590/ S0100-736X2014001100006>

Ceci L., Girolami F., Capucchio M.T., Colombino E., Nebbia C., Gosetti F., Marengo E., Iarussi F. \& Carelli G. 2020. Outbreak of Oleander (Nerium oleander) poisoning in dairy cattle: clinical and food safety implications. Toxins 12(8):471. <https://dx.doi.org/10.3390/toxins12080471> $<$ PMid:32722138>

Cook D., Lee S.T., Taylor C.M., Bassüner B., Riet-Correa F., Pfister J.A. \& Gardner D.R. 2014. Detection of toxic monofluoroacetate in Palicourea species. Toxicon 80(1):9-16. <https://dx.doi.org/10.1016/j.toxicon.2013.12.003> <PMid:24440601>

Correia D.A.B., Neto G.B.M., Gomes D. L.S. \& Torres M.B.A.M. 2017. Malformações congênitas e abortos induzidos experimentalmente pela ingestão de Poincianella pyramidalis (Tul.) L.P. Queiroz (catingueira) em ovelhas. Pesq. Vet. Bras. 37(12):1430-1436. <https://dx.doi.org/10.1590/s0100736x2017001200012>

Costa A.M.D., Souza D.P.M., Cavalcante T.V., Araújo V.L., Ramos A.T. \& Maruo V.M. 2011. Plantas tóxicas de interesse pecuário na região do Ecótono Amazônia e cerrado. Parte II: Araguaína, Norte do Tocantins. Acta Vet. Bras. 5(3):317-324. <https://dx.doi.org/10.21708/AVB.2011.5.3.2349>

Coutinho L.T., Costa N.A., Mendonça C.L., Afonso J.A.B., Riet-Correa F., Dantas A.F.M. \& Silva N.A.A. 2013. Intoxicação natural de bovinos leiteiros por Cestrum Laevigatum (Solanaceae) no Agreste de Pernambuco - Brasil. Ciênc. Anim. Bras. 14(3):352-359. <https://dx.doi.org/10.5216/cab.v14i3.13476>

Faccin T.C., Riet-Correa F., Rodrigues F.S., Santos A.C., Melo G.K.A., Silva J.A., Ferreira R., Ítavo C.C.B. \& Lemos R.A.A. 2014. Poisoning by Brachiaria brizantha in flocks of naïve and experienced sheep. Toxicon 82:1-8. <https://dx.doi.org/10.1016/j.toxicon.2014.02.008><PMid:24561120>

Figueiredo A.P.M., Medeiros R.M.T., Dantas F.P.M., Leite A.L.D., Fighera R.A., \& Riet-Correa F. 2012. Intoxicação experimental por Indigofera suffruticosa em caprinos e ovinos. Pesq. Vet. Bras. 32(2):126-130. <https://dx.doi. org/10.1590/S0100-736X2012000200006>

Grecco F.B., Dantas A.F., Riet-Correa F., Leite C.G. \& Raposo J.B. 2002. Cattle intoxication from Enterolobium contortisiliquum pods. Vet. Hum. Toxicol. 44(3):160-162. <PMid:12046969> 
Guaraná E.L.S., Riet-Correa F., Mendonça C.L., Medeiros R.M.T., Costa N.A. \& Afonso J.A.B. 2011. Intoxicação por Solanum paniculatum (Solanaceae) em bovinos. Pesq. Vet. Bras. 31(1):59-64. <https://dx.doi.org/10.1590/ S0100-736X2011000100009>

IBGE 2017. Censo Agropecuário. Instituto Brasileiro de Geografia e Estatística, Rio de Janeiro. Available at <https://censoagro2017.ibge.gov.br/templates/ censo_agro/resultadosagro/index.html> Accessed on Apr. 16, 2020.

Knupp S.N.R., Borburema C.C., Araújo V.O., Silva T.K.F., Riet-Correa F., Knupp L.S. \& Lucena R.B. 2018. Fotossensibilização primária em bovinos leiteiros causada por Froelichia humboldtiana. Pesq. Vet. Bras. 38(5):811-816. <https://dx.doi.org/10.1590/1678-5150-pvb-5238>

Lee S.T., Cook D., Riet-Correa F., Pfister J.A., Anderson W.R., Lima F.G. \& Gardner D.R. 2012. Detection of monofluoroacetate in Palicourea and Amorimia species. Toxicon 60(5):791-796. <https://dx.doi.org/10.1016/j. toxicon.2012.05.029>

Lemos R.A.A., Ferreira L.C.L., Silva S.M., Nakazato L. \& Salvador S.C. 1996. Fotossensibilização e colangiopatia associada a cristais em ovinos em pastagem com Brachiaria decumbens. Ciência Rural 26(1):109-113. <https://dx.doi.org/10.1590/S0103-84781996000100020>

Lima D.D.C.C., Albuquerque R.F., Rocha B.P., Barros M.E.G., Gardner D.R., Medeiros R.M.T., Riet-Correa F. \& Mendonça F.S. 2013. Doença de depósito lisossomal induzida pelo consumo de Ipomoea verbascoidea (Convolvulaceae) em caprinos no semiárido de Pernambuco. Pesq. Vet. Bras. 33(7):867-872. <https://dx.doi.org/10.1590/S0100-736X2013000700007>

Macedo J.T.S.A., Riet-Correa F., Dantas A.F.M. \& Simões S.V.D. 2008. Doenças da pele em caprinos e ovinos no Semi-árido brasileiro. Pesq. Vet. Bras. 28(12):633-642.<https://dx.doi.org/10.1590/S0100-736X2008001200013>

Marinho J.B.R., Carvalho A.U., Pierezan F., Kellers K., Riet-Correa F., Melo M.M., \& Soto-Blanco B. 2018. Comparação dos efeitos das folhas de Cestrum axillare Vell. com as saponinas isoladas em caprinos. Pesq. Vet. Bras. 38(5):852-861. <https://dx.doi.org/10.1590/1678-5150-pvb-5244>

Matsuura H.N., Porto D.D. \& Fett-Neto A.G. 2013. Bioactive alkaloids from South American Psychotria and related Rubiaceae. Natural Products. 119147. <https://dx.doi.org/10.1007/978-3-642-22144-6_101>

Mello G.W.S., Oliveira' D.M., Carvalho C.J.S., Pires L.V., Costa F.A.L., Riet-Correa F. \& Silva S.M.M. 2010. Plantas tóxicas para ruminantes e equídeos no Norte Piauiense. Pesq. Vet. Bras. 30(1):1-9. <https://dx.doi.org/10.1590/ S0100-736X2010000100001>

Mendonça F.S., Albuquerque R.F., Evêncio-Neto J., Freitas S.H., Dória R.G., Boabaid F.M., Driemeier D., Gardner D.R., Riet-Correa F. \& Colodel E.M. 2012. Alpha-mannosidosis in goats caused by the swainsonine-containing plant Ipomoea verbascoidea. J. Vet. Diag. Invest. 24(1):90-95. <https://dx.doi. org $/ 10.1177 / 1040638711425948><$ PMid:22362938>

Mendonça F.S., Evêncio-Neto J., Evêncio L.B., Dória R.G.S., Freitas S.H., Pellegrini L.F., Cruz R.A.S., Ferreira E.V. \& Colodel E.M. 2009. Natural and experimental poisoning of cattle by Enterolobium contortisiliquum pods (Fabaceae Mimosoideae) in Central-Western Brazil. Acta Vet. Brno. 78(4):621-625. <https://dx.doi.org/10.2754/avb200978040621>

Mendonça F.S., Silva Filho G.B., Chaves H.A.S., Aires L.D.A., Braga T.C., Gardner D.R., Cook D. \& Buril M.T. 2018. Detection of swainsonine and calystegines in Convolvulaceae species from the semiarid region of Pernambuco. Pesq. Vet. Bras. 38(11):2044-2051.<https://dx.doi.org/10.1590/1678-5150-pvb-5945>

Mendonça M.F.F., Pedroso P.M.O., Pimentel L.A., Madureira K.M., Macêdo J.T.S.A., D'Soares C.S., Silva A.W.O. \& Peixoto T.C. 2020. Epidemiological aspects of natural poisoning by Prosopis juliflora in ruminants in semiarid areas of the state of Bahia, Brazil, invaded by the plant. Pesq. Vet. Bras. 40(7):501-513. <https://dx.doi.org/10.1590/1678-5150-pvb-6664>

Nascimento E.M., Medeiros R.M.T \& Riet-Correa F. 2018. Plantas tóxicas para ruminantes e equídeos do estado de Sergipe. Pesq. Vet. Bras. 38(5):835839. <https://dx.doi.org/10.1590/1678-5150-pvb-5408>

Ogliari D., Molossi F.A., Savaris T., Wicpolt N.S., Zancan I. \& Gava A. 2018. Intoxicação espontânea por Brachiaria híbrida cv mulato I em ovinos e caprinos e experimental por Brachiaria híbrida cv mulato II em ovinos. Pesq. Vet. Bras. 38(2):229-233. <https://dx.doi.org/10.1590/1678-5150-pvb-4747>
Olinda R.G., Medeiros R.M.T., Dantas A.F.M., Lemos R.A.A. \& Riet-Correa F. 2015. Intoxicação por Enterolobium contortisiliquum em bovinos na região Nordeste do Brasil. Pesq. Vet. Bras. 35(1):44-48. <https://dx.doi org/10.1590/S0100-736X2015000100010>

Oliveira C.A., Barbosa J.D., Duarte M.D., Cerqueira V.D., Riet-Correa F., Tortelli F.P \& Riet-Correa G. 2009. Intoxicação por Ipomoea carnea subsp. Fistulosa (Convolvulaceae) em caprinos na Ilha do Marajó, Pará. Pesq. Vet. Bras. 29(7):583-588. <https://dx.doi.org/10.1590/S0100-736X2009000700014>

Pedroso P.M.O., Bandarra P.M., Bezerra Júnior P.S., Raymundo D.L., Borba M.R., Leal J.S. \& Driemeier D. 2009. Intoxicação natural e experimental por Nerium oleander (Apocynaceae) em bovinos no Rio Grande do Sul Pesq. Vet. Bras. 29(5):404-408. <https://dx.doi.org/10.1590/S0100736X2009000500008>

Pedroso P.M.O., Pinheiro E.E.G., Oliveira R.S. \& Macêdo J.T.S.A. 2018. Plantas tóxicas para animais de produção na Região do Recôncavo da Bahia. Revta Bras. Hig. Sanid. Anim. 12(1):120-132. <https://dx.doi.org/10.5935/19812965.20180012>

Pedroza H.P. 2015. Psychotria hoffmannseggiana: uma nova espécie de planta tóxica para bovinos. Master's Thesis, Escola de Veterinária, Universidade Federal de Minas Gerais, Belo Horizonte, MG. 41p.

Riet-Correa F., Medeiros R.M.T. \& Bezerra C.W.C. 2011. Plantas Tóxicas do Nordeste. Editora Sociedade Vicente Palloti, Patos. 78p.

Silva D.M., Riet-Correa F., Medeiros R.M.T. \& Oliveira O.F. 2006. Plantas tóxicas para ruminantes e equídeos no Seridó Ocidental e Oriental do Rio Grande do Norte. Pesq. Vet. Bras. 26(4):223-236. <https://dx.doi.org/10.1590/ S0100-736X2006000400007>

Silva F.F. \& Silva Júnior F.F. 1996. Intoxicação por Cestrum Laevigatum Schlecht em bovinos na microrregião de Garanhuns - PE. Cad. Ômega Univ. Fed. Sér. Vet., Recife, (7):15-21.

Silva Filho G.B., Chaves H.A.S., Albuquerque R.F., Souza P.E., Vieira M.E.Q., Nascimento A.L.O., Lima S.C. \& Mendonça F.S.M. 2020. Spontaneous and experimental poisoning by Froelichia humboldtiana in cattle. Pesq. Vet. Bras. 40(1):1-6. <https://dx.doi.org/10.1590/1678-5150-pvb-6351>

Soto-Blanco B., Fontenele-Neto J.D., Silva D.M., Reis P.F.C.C. \& Nóbrega J.E. 2006 Acute cattle intoxication from Nerium oleander pods. Trop. Anim. Health Prod. 38(6):351-354. <https://dx.doi.org/10.1007/s11250-006-4400-x> <PMid:17243471>

Souza M.F., Bezerra I.T.F., Barbosa F.M.S., Rocha V.C., Sousa M.S., Oliveira-Neto T.S., Lucena P.B.L \& Lucena R.B. 2018. Abortos, malformações congênitas e falhas reprodutivas espontâneas em caprinos causados na intoxicação pelas folhas da catingueira, Poincianella pyramidalis (sin. Caesalpinia pyramidalis). Pesq. Vet. Bras. 38(6):1051-1057. <https://dx.doi.org/10.1590/16785150-pvb-5243>

Souza P.E.C., Oliveira S.S., Aguiar-Filho C.R., Cunha A.L.B., Albuquerque R.F., Evêncio-Neto J., Riet-Correa F. \& Mendonça F.S. 2012. Primary photosensitization in cattle caused by Froelichia humboldtiana. Res. Vet. Sci. 93(3):1337-1340. <https://dx.doi.org/10.1016/j.rvsc.2012.04.005> $<$ PMid:22575746>

Taylor C.M. \& Gereau R.E. 2013. The genus Carapichea (Rubiaceae: Psychotrieae). Ann. Missouri Bot. Gard. 99(1):100-127. <https://dx.doi org $/ 10.3417 / 2011064>$

Taylor C.M. 1996. Overview of the Psychotrieae (Rubiaceae) in the Neotropics. Opera Bot. Belg. 7:261-270.

Taylor C.M., Lorence D.H. \& Gereau R.E. 2010. Rubiacearum americanarum magna hama pars XXV: the nocturnally flowering Psychotria domingensisCoussarea hondensis group plus three other Mesoamerican Psychotria species transfer to Palicourea. Novon, J. Bot. Nomenclature 20(4):481-492. <https://dx.doi.org/10.3417/2009124>

Tokarnia C.H., Brito M.F., Barbosa J.D., Peixoto P.V. \& Döbereiner J. 2012. Plantas Tóxicas do Brasil. $2^{\text {a }}$ ed. Editora Helianthus, Rio de Janeiro. 586p.

Vinuto J. 2014. A amostragem em bola de neve na pesquisa qualitativa: um debate aberto. Temáticas, Campinas, 22(44):203-220. <https://dx.doi. org/10.20396/tematicas.v22i44.10977> 